\title{
VALIDATION OF ANTIBODY RAPID TEST FOR SEVERE ACUTE RESPIRATORY SYNDROME CORONAVIRUS-2 INFECTION IN BETHESDA HOSPITAL YOGYAKARTA
}

\author{
Fenty $^{\left.1^{*}\right)}$, Ivan Lim ${ }^{1}$., Frida E. W², Kristiani $D^{2}$., Rizaldi Pinzon ${ }^{2}$ \\ ${ }^{1}$ Faculty of Pharmacy, Sanata Dharma University, Paingan, Maguwoharjo, Depok, Sleman, \\ Yogyakarta, 55282, Indonesia \\ ${ }^{2}$ Bethesda Hospital Yogyakarta, 55224, Indonesia
}

Received November 15, 2020; Accepted July 13, 2021

\begin{abstract}
Since March 2020, Severe Acute Respiratory Syndrome Coronavirus-2 (SARS-CoV-2) infection has been around in Indonesia with a case fatality rate was $4.7 \%$ on August, $1^{\text {th }} 2020$. So far, the Real-Time Polymerase Chain Reaction (RT-PCR) method is the gold standard for the SARS-CoV-2 infection diagnosis. This method, however, has some limitations where it has a long turnaround time, complicated operations, and high prices. Hence, the rapid test kits are now readily available to identify the SARS-CoV-2 patients. The purpose of this study is to measure the diagnostic performance, including sensitivity, specificity, positive and negative predictive value, likelihood ratio or LR of antibody rapid test if compared with RT-PCR for the SARS-CoV-2 suspected patients in Bethesda Hospital Yogyakarta. This research was analytical observational research with a cross-sectional design approach, in which data were collected retrospectively. The instruments used in this study included e-medical record (ERM), Laboratory Information System (LIS) data from patients with suspected SARS-CoV-2 infection in Bethesda Hospital Yogyakarta. We collected demographic data of patients, RT-PCR results, antibody rapid test results using Standard Q COVID-19 IgM/IgG Combo. The data were obtained from 50 patients. The results showed that the Rapid test kit has a $100 \%$ sensitivity value, $74.4 \%$ specificity value, $38.9 \%$ positive and $100 \%$ negative predictive value, 3906 positive likelihood ratio compared with the RT-PCR results.
\end{abstract}

Keywords: Rapid antibody test; RT-PCR; SARS-CoV-2

\section{INTRODUCTION}

Severe Acute Respiratory Syndrome Coronavirus-2 (SARS-CoV-2) infection is an ongoing respiratory disease outbreak caused by Coronavirus that firstly emerged in Wuhan City, China, in December 2019 (WHO, 2020). Since the first case of the disease was reported at the end of 2019 in Wuhan, it has spread widely to entire China and multiple countries (WHO, 2020).

According to the statistic information from the Indonesian Health Ministry on August, $1^{\text {st }} 2020$, there were 109,936 cases confirmed for SARS-CoV-2, which divided into 36,824 active cases, 67,919 cured cases, and 5193 death cases. There are 1,517,381 specimen tested coming from 875,894 Indonesian citizens. In Daerah Istimewa Yogyakarta, there were 10,126 suspected cases, 741 confirmed cases, 410 cured cases, and 21 death cases until August 1, 2020 (PEMDA DIY, 2020).

Indonesia has recorded an $8.4 \%$ fatality rate in April 2020 and decreased to $4.72 \%$ in August 2020. Meanwhile, in August, the positivity rate in Indonesia was still $12.6 \%$, which was considered very high and exceeded the limit set by WHO (2020) that is less than 5\%. The increasing SARS-CoV-2 infection cases in Indonesia have caused a few complex problems, including the availability of facilities to screen and 
confirm a COVID-19 diagnosis. Currently, the Real-Time Polymerase Chain Reaction method (RT-PCR) is the gold standard of SARS-COV-2 testing (Kahfarhood et al., 2020).

However, there are some limitations to the RT-PCR method. It will need a certified laboratory with a specific classification for safety. It also takes a long time from sample preparation until the test result. Also, it is costly and complicated in operations ( $\mathrm{Li}$ et al., 2020). Even though RT-PCR is the goldstandard method in diagnosing the SARSCoV-2 infection, the sensitivity of this method is only $50 \%$ to $70 \%$ due to the small number of virus particles in some infected patients. The best specimen for virus detection is Broncho Alveolar Lavage (BAL). However, until now, the test majorly takes the samples from the nasopharyngeal or oropharyngeal swabs. The false-negative could happen if the sampling quality or the sample management is poor. It could also give false-negative results in the early infection periods, or there is an analytical problem at the laboratory (Joseph, 2020; Susilo et al., 2020).

Because of these limitations, especially in this pandemic, we need simple and accurate testing to identify the SARS-CoV-2 infection quickly to prevent the virus from spreading and produce the proper handling for the suspected SARS-CoV-2 infection patient (Joseph, 2020; Li et al., 2020).

In this case, the government has widely distributed the rapid test kit to detect the antibody of SARS-CoV-2. Rapid test detection has many practical advantages, including quick test results, low cost, and patient convenience. This test can identify the carrier patients and patients without symptoms (Joseph, 2020; Li et al., 2020).

Moreover, many companies have developed Rapid test kits to detect human antibodies in SARS-CoV-2 patients (Guo et $a l .$, 2020). A rapid test needs reconsidering of the exposure onset and symptoms duration before deciding the results. In this case, the test can detect the IgM and IgA sooner. It is detected three up to six days after the onset of the symptoms. Meanwhile, it detects the IgG within 10 to 18 days after the initial symptoms (Guo et al., 2020).

In April 2020, the COVID-19 team for West Java province, Indonesia, performed a validation test for rapid test using 'Wondfo' compared with the RT-PCR. The sensitivity, specificity, and accuracy rates in serum specimens in that test were $62.9 \%, 95.2 \%$, and $77.1 \%$, respectively. Meanwhile, in the capillary, the rates were $44.4 \%, 100 \%$, and $54.4 \%$ taken from 22 samples (Tim Tanggap COVID-19, 2020). Li et al. (2020) stated that the antibody-rapid test showed $88.66 \%$ sensitivity and $90.63 \%$ specificity, measured from 397 confirmed patients with RT-PCR and 128 negative patients in eight health facilities.

Since the rapid-test kits may have varied sensitivity and specificity values, a validation test for the rapid-test compared with the RTPCR is crucial, especially concerning the situation of the outbreak in Indonesia. This research took place at Bethesda Hospital because it is one of the referral hospitals in Yogyakarta.

The purpose of this study is to measure the diagnostic performances, including sensitivity, specificity, accuracy, positive predictive value, negative predictive value, and likelihood ratio of the antibody-rapid test compared with the RT-PCR as the best method for the SARS-CoV-2 suspected patient in Bethesda Hospital, Yogyakarta.

\section{METHODS}

This study was analytical observational research with a cross-sectional design approach, and data sampling was collected retrospectively. The research variables were SARS-CoV-2 antibody rapid test as independent variable and SARS-CoV-2 RTPCR as dependent variable.

Instruments in this study were electronic medical record (ERM) and Laboratory Information System (LIS) data from SARSCoV-2 suspected patients in Bethesda Hospital, Yogyakarta. We collected demographic data of patients with RT-PCR of SARS-CoV-2 results from the Center for 
Environmental Engineering and Disease Control (BBTKLPP) of Yogyakarta. Meanwhile, we obtained the antibody-rapid tests data using the Standard Q COVID-19 IgM/IgG Combo made in Korea. This study has the approval number No.99/KEPK/RSB-VII/20 issued by the Medical and Health Research Ethics Committee of Bethesda Hospital Yogyakarta, Indonesia.

This study began from May to June 2020. The inclusion criteria were SARS-CoV-2 suspected patient who was clinically determined by attending physician, taking nasopharyngeal/oropharyngeal swab RTPCR or antibody-rapid test, with no immunocompromised problems.
The validation test for the SARS-CoV-2 antibody rapid test of Standard Q COVID-19 with immunochromatography compared with SARS-CoV-2 RT-PCR was calculated using a $2 \times 2$ table with a $95 \%$ level of confidence, done with a diagnostic test calculator.

\section{RESULTS AND DISCUSSION}

Fifty subjects took the antibody-rapid test and had data on the results of the RTPCR examination, consisting of 24 males and 26 females. From May until June 2020, seven patients had confirmed SARS-CoV-2 infection based on the RT-PCR (Table 1).

Table 1. Characteristics of study subjects

\begin{tabular}{ll}
\hline Characteristics & $\mathbf{n}=\mathbf{5 0}(\mathbf{1 0 0} \%)$ \\
\hline Sex & $24(48 \%)$ \\
\hline Male & $26(52 \%)$ \\
\hline Female & $1(2 \%)$ \\
\hline Age & $49(98 \%)$ \\
\hline$<18$ years & \\
\hline$\geq 18$ years & $7(14 \%)$ \\
\hline RT-PCR & $43(86 \%)$ \\
\hline Positive &
\end{tabular}

Table 2. Comparison Ig M and Ig G to RT-PCR results

\begin{tabular}{lccc}
\hline & $\begin{array}{c}\text { RT-PCR } \\
\text { positive }\end{array}$ & $\begin{array}{c}\text { RT-PCR } \\
\text { negative }\end{array}$ & Total \\
\hline Ig M reactive & 4 & 23 & 27 \\
\hline Ig M non reactive & 3 & 20 & 23 \\
\hline Total & 7 & 43 & 50 \\
\hline Ig G reactive & 6 & 11 & 17 \\
\hline Ig G non reactive & 1 & 32 & 33 \\
\hline Total & 7 & 43 & 50 \\
\hline
\end{tabular}

Table 3. Comparison Ig M/Ig G to RT-PCR results

\begin{tabular}{lccc}
\hline & $\begin{array}{c}\text { RT-PCR } \\
\text { positive }\end{array}$ & $\begin{array}{c}\text { RT-PCR } \\
\text { negative }\end{array}$ & Total \\
\hline Ig M/Ig G reactive & 7 & 11 & 18 \\
\hline Ig M/Ig G non reactive & 0 & 32 & 32 \\
\hline Total & 7 & 43 & 50 \\
\hline
\end{tabular}

According to Table 2 and 3, there were four reactive IgM and six reactive $\mathrm{IgG}$ from seven positive confirmed RT-PCR. Three patients had reactive IgM and $\mathrm{IgG}$, and only three patients had a reactive $\mathrm{IgG}$, while only one patient had a reactive $\operatorname{IgM}$. Based on the Standard Q COVID-19 IgM/IgG Combo leaflet, individuals with reactive results for
$\operatorname{IgM}$ or $\operatorname{IgG}$ will show a reactive antibody SARS-CoV-2 result.

From the seven positive confirmed patients by RT-PCR, the antibody SARSCoV-2 could show reactive results between 7 to 14 days after the onset (two patients) and more than 14 days after the initial symptom (three patients). Also, two asymptomatic 
patients were confirmed positive by RT-PCR. Meanwhile, Table 4, 5, and 6 show the validation tests for the antibody rapid test Standard Q COVID-19 IgM/IgG Combo compared with RT-PCR. Based on the tables, the validation test result for Standard Q COVID-19 IgM/IgG Combo, the antibody IgG was better than IgM.

Table 4. Validity of IgM to RT-PCR results

\begin{tabular}{|c|c|c|}
\hline Variable & Results & $95 \% \mathrm{CI}$ \\
\hline Sensitivity & 0.571 & $0,25-0,842$ \\
\hline Specificity & 0,465 & $0,325-0,611$ \\
\hline PPV & 0,148 & $0,059-0,325$ \\
\hline NPV & 0,870 & $0,679-0,955$ \\
\hline $\mathrm{LR}+$ & 1,067 & $0,531-2,15$ \\
\hline LR- & 0,923 & $0,37-2,297$ \\
\hline
\end{tabular}

Table 5. Validity of IgG to RT-PCR results

\begin{tabular}{|c|c|c|}
\hline Variable & Results & $95 \% \mathrm{CI}$ \\
\hline Sensitivity & 0,857 & $0,487-0,974$ \\
\hline Specificity & 0,744 & $0,598-0,851$ \\
\hline PPV & 0,353 & $0,173-0,587$ \\
\hline NPV & 0,970 & $0,847-0,995$ \\
\hline $\mathrm{LR}+$ & 3,348 & $1,852-6,061$ \\
\hline LR- & 0,192 & $0,031-1,188$ \\
\hline
\end{tabular}

Table 6. Validity of $\mathrm{IgM} / \mathrm{IgG}$ to RT-PCR results

\begin{tabular}{|c|c|c|}
\hline Variable & Results & $95 \% \mathrm{CI}$ \\
\hline Sensitivity & 1 & $0,646-1$ \\
\hline Specificity & 0,744 & $0,598-0,851$ \\
\hline PPV & 0,389 & $0,203-0,614$ \\
\hline NPV & 1 & $0,893-1$ \\
\hline $\mathrm{LR}+$ & 3,906 & $2,348-6,508$ \\
\hline
\end{tabular}

According to the manufacturer, the specificity evaluation was done on 235 PCRnegative samples and turned out to be $95.74 \%$ for both $\operatorname{IgM}$ and IgG. The sensitivity of this test compared to the RTPCR from 66 specimens between 7 to 14 days after onset was $89.39 \%$ for IgM/IgG, while from other 98 samples within 14 days after onset was $96.94 \%$ for $\operatorname{IgM} / \mathrm{IgG}$ (SD biosensor, 2020). On the other hand, our results showed that the specificity value from 43 patients with negative RT-PCR was $74.7 \%$, while the sensitivity value from seven patients with positive RT-PCR was 100\%. Positive Predictive Value (PPV) was $38.9 \%$, meaning that $61.6 \%$ reactive result from this test showed a false-positive compared with the RT-PCR result. Negative Predictive Value (NPV) was 100\%, meaning that the non-reactive result from this test showed that the patient did not get infected by SARS-CoV-2 based on the RT-PCR.
Meanwhile, the likelihood ratio (LLR) value was equal to 3,906 , denoting that in every one false positive, there were four correct positive results. The greater the positive likelihood ratio value is, the better it is to detect disease (Putra et al., 2016).

In July 2020, the Indonesian Association of Clinical Pathologists and Laboratory Medicine (PDS PATKLIN) studied 63 different kinds of SARS-CoV-2 antibody rapid tests from the communities and hospitals in all the branches of PDS PATKLIN in Indonesia. The result of the study showed that the accuracy of SARSCoV-2 antibody rapid tests varied greatly. The sensitivity and specificity of IgG ranged around $33 \%$ to $96 \%$ and $19 \%$ to $100 \%$. Meanwhile, the sensitivity and specificity of IgM ranged between $16 \%$ to $100 \%$ and $7 \%$ to $97 \%$, respectively. 
However, the result of our study showed that the combination between the antibody SARS-CoV-2 Standard Q COVID-19 Combo IgG and IgM had better accuracy if compared to either IgG or IgM only, and the performance of $\mathrm{IgG}$ was better than $\operatorname{IgM}$. Detection of $\operatorname{IgM}$ antibodies is often interpreted as an indicator of acute infection, while the detection of IgG antibodies represents previous infection/immunity (Castro et al., 2020). Yet, in this study, we found three samples with positive RT-PCR results that were only reactive IgG. It showed that IgG could appear in the acute phase. Our result was consistent with the PDS PATKLIN survey. Long et al. (2020) found that IgM seroconverted later than IgG. Thus, they recommended that either $\operatorname{IgM}$ or $\operatorname{IgG}$ seroconversion become a confirmation criterion of recent SARS-CoV-2 infection.

So far, the RT-PCR method has some limitations that involve the quality of specimens, long turnaround times, complicated operations, fluctuations of viral load in different phases of SARS-CoV-2 infection, virus mutation probability, and high prices. Therefore, the antibody-rapid test is advisable, especially in screening the specific population, individual traveling, and contact tracing (Li et al., 2020; Long et al., 2020; Kemenkes RI, 2020).

Based on Prevention Guidelines for COVID-19, Fifth Revision Edition, the rapid test was no longer recommended for diagnosis. However, the study of Guo et al. (2020) stated that the positive detection rate increased by using combinations of antibody rapid test and RT-PCR, especially if there was a false negative from RT-PCR result from the patient with highly suspected SARS-CoV-2.

Meanwhile, our study has its limitations. Firstly, the proportion of confirmed positive cases for SARS-COV-2 was relatively small (seven patients only) and from only one health facility center (Bethesda Hospital).

\section{CONCLUSION}

The Standard Q COVID-19 IgM/IgG Combo rapid test had a $100 \%$ sensitivity value, $74.4 \%$ specificity value, $38.9 \%$ positive predictive value, $100 \%$ negative predictive value, and 3,906 positive likelihood ratio.

\section{REFERENCES}

Castro, R., Luz, P.M., Wakimoto, M.D., Velozo, V.G., Grinsztejn, B., Perraxo, H., 2020. COVID- 19: a MetaAnalysis of Diagnostic Test Accuracy of Commercial Assays Registered in Brazil. Brazilian Journal of Infectious Diseases, 24(2), 180-187.

Diagnostic test calculator, 2020. URL https://ebm-

tools.knowledgetranslation.net/calcula tor/diagnostic/ (accessed 12.10.20).

Guo, L., Ren, L., Yang, S., Xiao, M.,Chang,Yang, F., et al., 2020. Profiling Early Humoral Response to Diagnose Novel Coronavirus Disease (COVID-19). Clin Infect Dis. Published online March 28. DOI:10.1101/2020.03.05.20030502.

Joseph, T. (editor in chief), 2020. International Pulmonologist's Consensus on COVID-19. $2^{\text {nd }}$ edition. [WWW Document]. URL https://www.researchgate.net/publicati on/340862051 COVID-19-E-

Book_International_Pulmonologist's_c onsensus on COVID-19 2nd_Edition (Accessed 24.04.20)

Kahfarhood, G., Aghaali, M., Saadati, H.M., Taherpoor, N., Rahimi, S., Izadi, N., \& Nazarari, $\quad$ S.S.H., 2020. Epidemiological and Clinical Aspect of COVID-19; A Narrative Rev. Archieves of Academic Emergency Medicine, 8(1), e41.

Kementerian Kesehatan RI, 2020. Gugus Tugas Percepatan Penanganan COVID-19. [WWW Document]. URL https://www.covid19.go.id/ (accessed 18.04.20). 
Kementerian Kesehatan RI, 2020. Infografis COVID-19 (24 Oktober 2020). [WWW Document] URL https://covid19.go.id/p/berita/infografi s-covid-19-24-oktober-2020 (accessed 24.10.20).

Kemeterian Kesehatan RI, 2020. Pedoman Pencegahan dan Pengendalian Coronavirus Disease (COVID-19). Revisi Kelima.

Li X., Geng M., Peng Y., Meng L., Lu S., 2020. Molecular Immunepathogenesis and Diagnosis of COVID-19. Pharm Anal. Published online March 5. DOI: 10.1016/j.jpha.2020.03.001.

Li Z., Yi Y., Luo X., Xiong N., Liu Y., LiS., et al., 2020. Development and Clinical Application of a Rapid IgM-IgG Combined Antibody Test for SARSCoV-2 Infection Diagnosis. Journal of Medical Virology. DOI:10.1002/jmv.25727.

Long, Q., Deng H., Chen J., Hu J., Liu B.,Liao P., et al., 2020. Antibody responses to SARS-CoV-2 in COVID19 Patients: The Perspective Application of Serological Tests in Clinical Practice. MedRxiv, 20 March 2020.

DOI: 10.1101/2020.03.18.20038018.

Lu, H., Startton, C.W., Tang, Y.W., 2020. Outbreak of Pneumonia of Unknown Etiology in Wuhan, China: The Mystery and the Miracle. Journal of Medical Virology, 92(4).

Pemda DIY, 2020. Laporan Harian COVID19. [WWW Document]. URL https://corona.jogjaprov.go.id(accesse d 24.10.20).
Putra, I.W.G.A.E., Sutarga, I.M., Kardiwinara, M.P., Suariyani, W.L.P., Septarini, N.W., \& Subrata, I.M., 2016. Modul Penelitian Uji Diagnosis dan Skrining. Program Studi Kesehatan Masyarakat Fakultas Kedokteran Universitas Udayana.

PDS PatKlin, 2020. Hasil survey Performa RDT Antibodi SARS COV-2. (Power Point Presentation). Perhimpunan Dokter Spesialis Patologi Klinik dan Kedokteran Laboratorium Indonesia.

SD Biosensor. Standard Q COVID-19 IgM IgG Combo. [WWW Document]. URL

http://sdbiosensor.com/xe/product/125 09 (accessed 20.10.20).

Susilo, A., Rumende CM., Santoso WD., Yulianti M., Herikurniawan., et al., 2020. Coronavirus Disease 2019: Tinjauan Literatur Terkini. Jurnal Penyakit Dalam Indonesia, 7(1), 4567.

Tim Tanggap Covid-19, 2020. Uji Validasi Tes Cepat antibody 'Wondfo' dibandingkan dengan RTPCR pada pasien terduga COVID-19 di RSUP Dr. Hasan Sadikin, Bandung. JawaBarat.

World Health Organization, 2020. Laboratory Testing for Coronavirus Disease 2019 (COVID-19) in Suspected Human Cases. Geneva: World Health Organization.

World Health Organization, 2020. Coronavirus Disease 2019 (COVID-19) Situation Report-28. [WWW Document] URL Who.int/Indonesia (accessed 24.20.20). 